\title{
Cultural Bias and Chinese History
}

I infringe the generally sound principle that one should never try to reply to reviewers to respond to Jerome Grieder's long review (JAS, XXXIII, May I974, pp. 462-66) of my volume on China (of a two-volume work entirled The West in Russia and (hina). It is a curious review. Grieder plainly does not like the book. However, he finds no single factual error, and challenges no single interpretive statement. Most of the review is devoted to making broad charges against me, chiefly that my whole understanding of the Sino-Western intellectual relationship is "flawed by prejudice" and is "imprisoned in the rigid judgments born of adamantine moral certainty." Since he never explains against what or whom he thinks me prejudicedthough reviewers ought to explain and support their charges, or editors should ask thern to do so-I cannot speak to the first accusation. As to "moral certainty," I shall comment later.

There are many rhetorical questions. Is spherical trigonometry the product of Christian culture, or Western culture? "Must the latter be regarded as contingent upon the former, and if so, why and how?" I am said to "owe" readers clearer answers to these questions. I fail to see why I am obliged to pronounce upon the contingency of spherical trigonometry to the culture in which it arose, or other comparable questions-which might be easily prolonged endlessly. (Did Chartres cathedral arise through the technical skills or the faith of the town's twelfth-century inhabitants? Were the builders good architects, Christians, or Westerners? How? Why? Tell us, Treadgold.) In the introduction I discuss Max Weber's statements about the "universal" significance and value of Western cultural phenomena, and associate myself with those who do not believe that cultural phenomena of universal significance appeared only in the West. Perhaps Grieder should have attached his epithets of "prejudice" and "moral certainty" to Weber instead of me. He declares that I give the impression that the "Chinese awaited only the advent of saviors from afar to release them from the bondage of their own culture." I point out that no influential Chinese thinker who had had substantial exposure to the West wanted to reject it entirely, and that a number whom I call "syncretists" did wish to preserve the best in their own culture while accepting certain Western importations. They included Hsü Kuang-ch'i and Li Chih-tsao, Hung Jen-kan, K'ang Yu-wei and Liang $\mathrm{Ch}^{\prime} \mathrm{i}$-ch'ao, and others. Which influential Chinese thinkers have I left out? Or is Grieder simply doing what he accuses me of doing, seeing facts "through the medium of his convictions as to the preferable (and therefore possible?) ends of China's modern history"?

I am next charged with lacking the sympathy which is due the nineteenth-century pietists, since the real cause of their shortcomings is that of "the divorce of Faith from Reason," of which process the pietists "were more the victims than the masters." Grieder evidently wants me to add a footnote to the story I tell of the limited and short-sighted majority (though I also give much space to the perceptive and humane minority), to explain that it wasn't really their fault. Shall I also say of the early Jesuits and certain Westerners of the twentieth century, ending with the Communists, that what they achieved was not really because of their own merits? If all that thinkers (or people who don't think very well but whose ideas are nevertheless influential) do is reflect other "forces" (Grieder's word), then there is little point in writing intellectual history. 
The charges become a bit clearer when I am said to have an "ex parte preoccupation with 'religious' and specifically Christian themes." (I do write about Jesuits, pietists, and other Christians-the only Westerners to have an impact on Chinese culture during the period in question. Grieder surely doesn't charge me with being responsible for that fact?) My "preoccupation," he continues, "tends most conspicuously to distort the evidence and the conclusions drawn from it." Again no distortion of evidence whatever is specified, so I can say nothing about that.

Finally Grieder comes down to it. He is unable to understand what I mean by the "category of truth," for he explicitly confuses it with the category of goodness (or justice), though I distinguish the two throughout. He then attributes that confusion to me-hence the charge of "moral certainty." I assume, he alleges, "not only the moral supremacy of Western Christian civilization over the morally lethargic traditions of China and the morally delinquent regime of the present time, but moreover [take] as terms of fixed content some of the most suggestive [sic] and troublesome language of the Western tradition itself." (Nowhere do I say or imply that the Confucian tradition was "morally lethargic" or the present regime "morally delinquent." I do not discuss the morality of the present regime at all, but I know that it is very hard indeed on moral delinquency of many kinds, in a puritanical manner quite comparable with the ethos of Stalin's USSR.) What is that "troublesome" language that annoys Grieder? The term "truth." I plead guilty. What Grieder must fear is that I have determined what is true, beautiful, and good; and that I am eager to inflict my answers on other people, perhaps by compulsion. Since ancient Greece, those categories have occupied Westerners; and some have certainly misused them. If Grieder thinks I am personally dangerous, I wish he would say so; the fact that I take the central categories of the Western tradition seriously in critical analysis is not, in my view, anything requiring apology. His final shot is that my "purpose" is "indeed culture-bound." The whole book is filled with sympathetic concern for those who sought to preserve the values of the Chinese tradition against those who regarded them as outmoded or obstructive of the kinds of change they desired. If Grieder does not discern that, it can only be because he has somehow decided that 1 cannot mean what I say, from beginning to end.

I am sorry that Grieder doesn't like my treatment of the story of Sino-Western intellectual relations. I think, however, that what he dislikes even more is what actually happened.

DONALD W. TREADGOLD

University of Wasbington 